\title{
Contestation of Perspectives Toward Suicide in The Film Monsieur Lazhar (2011) by Philippe Falardeau
}

\author{
Tesya Imanisa Setiadi', Wening Udasmoro², Hayatul Cholsy ${ }^{3}$ \\ Universitas Gadjah Mada',2,3 \\ Email: udasmoro@ugm.ac.id ${ }^{2}$
}

Submitted: 07/09/2020

Revised: 04/01/2021

Accepted: 17/01/2021

E-ISSN : $2579-4574$

P-ISSN : 2549-7359

\begin{abstract}
Suicide is one of the causes of death that occurs in a global scope but always causes divisive perspectives in various circles of society. For most people, suicide is a taboo topic, but not for other groups. The film Monsieur Lazhar (2011) is a film that shows the different perspectives between different age groups, namely the adult age group and the young age group, on a suicide that occurred at an elementary school in Montreal, Canada. This study aims at determining the different perspectives of the two different parties on suicide and the reasons for these differences in views. Pierre Bourdieu's Champ de Force theory is the lens used in this research. The difference in perspective is influenced by the disposition system which Bourdieu calls the habitus. Habitus operates in a realm (champ). In the film, the domain in question is school. Meanwhile, Durkheim's theory of suicide was chosen to determine the relationship of social problems to suicide. The method used in this research is content analysis. The data used are the chronological text of the scenes and the transcript of the conversations from the film. From the research, it was found that the school, which is the adult age group, has a counter and stigmatic view of suicide, reinforced by perceptions of psychological problems and social taboos. Meanwhile, students, who are in the young age group, tend to view suicide as a problem related to personal aspects and personal experiences so that they do not have a judgmental attitude like the school.
\end{abstract}

Keywords : Suicide, Contestation, Realm, Perspective, Habitus

https://ojs.unm.ac.id/eralingua

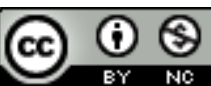

This work is licensed under a Creative Commons Attribution-NonCommercial 4.0 International License 


\section{INTRODUCTION}

Until today, suicide remains a controversial and taboo topic to discuss. However, data released by the World Health Organization (WHO) shows that every 40 seconds, worldwide, one person dies of suicide (Linggasari, 2015). This matter shows that suicide is a serious problem and is a reality faced in everyday life on a global scale. People who commit suicide have various reasons, ranging from psychological problems, economic problems, social environmental pressures, or various forms of violence and intimidation experienced during their life. From these various reasons, psychological conditions, one of which depression is often considered a strong trigger for someone to commit suicide. In various countries, many preventive efforts have been made, both in the form of social campaigns to increase public awareness of mental illness (Dumesnil \& Verger, 2009) and in the form of invitations to take advantage of consultation facilities for psychiatric experts (Harada et al., 2014).

For many countries and certain social groups, suicide is a stigmatized problem, particularly with regard to psychological problems. The risk of suicide is most often associated with psychological problems (Windfuhr \& Kapur, 2011). Stigma against psychological problems or mental illnesses, such as the perception that people with mental illness are dangerous and rejected in a social environment, are still serious problems that can make it difficult for sufferers to seek treatment and have a good quality of life (Hinshaw SP, 2007; Livingston JD \& Boyd JE, 2010 in Mannarini \& Boffo, 2015). The public's stigma against mental illness makes it difficult for people with these problems to talk about their problems because of the burdens of the social environment (Evans-Lacko et al., 2013).

The stigma attached to suicide can be related to religious practice. The theory of the relationship between religion and suicide was first built by Durkheim in the 19th century. Durkheim argued that Catholic groups had the lowest risk of suicide, meanwhile Protestant groups had the middle risk of suicide, and the highest was the groups not affiliated with religion. (O'Reilly \& Rosato, 2015). He argued that the level of individual belief in religion and the practice of its system had an influence on their integration of religion and a low risk of suicide (Stack \& Kposowa, 2011). In the context of the 19th century Europe, a religious system with a high number of religious beliefs and practices (prohibition of divorce and reconciliation, weekly attendance and activity in church, meatless Fridays, confession of sins, etc.) in Catholicism religion, had a higher level of integration than in Protestantantism (Stack \& Kposowa, 2011). Meanwhile, in the beliefs of various religions, suicide is considered a violation due to religious teachings that prohibit someone from committing suicide (Nursalam \& Nugrawati, 2018). In Islam, suicide is considered as haram act and a grave sin, the perpetrator is said to be subject to severe punishment in the afterlife (Al-Harrasi et al., 2016). In addition, modern Islamic thinkers have explained that the act of suicide shows a decrease in a person's faith due to commitment to religious teachings. (Leo, 2018; Stack \& Kposowa, 2011).

In France, suicide is a taboo topic. Talking about suicide is considered encouraging someone to follow this action (Quidu, 1983). However, a study conducted by the Directorate of Research, Studies, Evaluation and Statistics of the 
Ministry of Work, Social Cohesion and Housing in France in May 2006, shows that France is the country with the highest number of suicide. Suicide is the leading cause of death at 35-44 years of age and the second leading cause of death at age 15-24, with more than 11,000 deaths per year. This number does not include suicides that are "disguised" as accidents, addiction to addictive substances, falls from heights, and traffic accidents (Tichote, 2010). Most people consider suicide as an act of shame and difficult to accept, particularly for the family or relatives who are left behind.

Research on suicide has been widely carried out in the social and humanities field. Studies on suicide are mostly carried out to determine people's perspective on suicide, such as research in the field of psychology conducted by Na et al. (2018) entitled Association Between Age and Attitudes Toward Suicide. The study, was conducted in 16 provinces in Korea (except Jeju Island), aimed to determine the relationship between age and suicide. Many other studies have been conducted to look at people's perspective on suicide, for example the research conducted by Pereira et al. (2019) with the title Stigmatizing Attitudes Towards Suicide by Gender and Age which tried to look at the relationship between age and gender with a stigmatic view of suicidal behavior. Another study conducted by Foo et al. (2014) entitled Religious Commitment, Attitudes Toward Suicide, and Suicidal Behaviors Among College Students of Different Ethnic and Religious Groups in Malaysia tried to find out the influence of religion and ethnicity toward perspective concerning suicide.

On the other hand, although cases of suicide in the world are still developing and the problem of stigmatization is still valid, medical experts and the community concerned about humanity continue to make efforts to prevent and eliminate the stigma against suicide. Apart from conducting campaigns and invitations to take advantage of consultation facilities, media coverage of suicides also needs to follow guidelines in order to reduce stigma and contribute to reducing suicide cases (Siauw, 2018). Even though the stigma still occurs, the phenomenon of suicide receives sympathy from certain parties. This shows that there are now split two perspective of suicide. This issue was raised in the film Monsieur Lazhar which was released in 2011 in Canada. After a character named Bachir Lazhar took the place of a suicide teacher named Martine at an elementary school in Montreal, he was faced with various events that prompt him to bring up the topic of suicide. At the school, the recent suicide incident was taboo to discuss. However, some students wanted to express grief and talked about Martine, so they thought that the topic of suicide should be discussed at school.

This problem shows that in the film, there is a problem of different perspectives on suicide, which occurs between the school, who is an adult, and students who have an age range of 11 to 13 years old. This difference in perspective or point of view contributes to the contestation between the two parties. This research was conducted to find out what forms of meaning concerning suicide by two parties in a certain environment, and to find out the reasons for the different meaning of these parties. 


\section{RESEARCH METHOD}

The method used in this research is story content analysis. The first step is data collection. The data collected is in the form of a chronological text of the scene and transcript of the conversation from the film Monsieur Lazhar (2011). The primary data is obtained by heeding to and listening to French conversations and also the translation of the dialogue in Indonesian in the film. Both French and Indonesian data are used in this study as direct quotations. The second step is data classification. The data are classified according to emerging patterns, for example, the opinions of adults and young people considering suicide problems. The third step is data analysis. The dialogue between the empirical data contained in the novel with the theories of champs and the concepts of suicide are carried out to understand the meaning of suicide in these two different groups.

\section{RESULT AND DISCUSSION}

\section{Forms Of Constestation Of Meaning Toward Suicide}

The issue of stigmatization and different perspective of the two different groups on suicide in the film Monsieur Lazhar (2011) can be seen by observing the actions of the school and the students. Contestation of the opposing perspectives can be seen from various film scenes and the behavior of the characters. The two parties in the school interprete suicide differently.

\section{Suicide for The Senior Group}

The senior have different perspective from the junior toward the problem of suicide. This senior group is more interested in psychological problems and social problems when basing themselves on their meaning of suicide.

\section{Suicide and Psychological Problems}

Psychological issues are major aspects of the basic argument in suicide problem. For example, after a suicide occurs, schools are closed for a week. The school is trying to change the atmosphere of the school, including the classroom where the suicide incident occurred. In addition, they also removed Martine's belongings at school with the assumption to avoid trauma to the students. By the time the students return to school, Vaillancourt as the headmaster of the school brings in a psychologist who will accompany the students during the learning process at school for the next few weeks.

Vaillancourt : Je sais que ... la fin de semaine a été très dure. C'est important qu'on soit solidaires. On va passer à travers de ça ensemble, avec vos professeurs, avec vos parents, avec la psychologue ici, Julie Latendresse. Alors, Julie va nous aider à parler de ce qui s'est passé jeudi dernier.

Vaillancourt: I know... this weekend has been a very difficult time. It is very important for us to maintain solidarity. We will go through this time together, with the help of our teachers, parents, and with the psychologist here, Julie Latendresse. So here Julie is going to help us to talk about what happened last Thursday. (00.04.47) 
Vaillancourt's perception of suicide can be seen from his action in bringing psychologist to school. People who are left behind by suicide are perceived to have problems after witnessing events that are considered traumatic. Character perceptions in the form of associations with suicide and psychological problems are forms of stigma that lead to the notion that psychological disorders can lead to taking extreme actions in the form of suicide (Carpiniello \& Pinna, 2017).

The connection between suicide and psychological disorders is formed from instilling thought patterns or concepts from a particular group's environment. In Bourdieu's theory (Bourdieu, 2011: 174 in Karnanta, 2013), the framework is referred to habitus. Habitus is defined as a structure of experience stored in each organism in the form of patterns of perception, thought and action, which tend to ensure the suitability of practice and their consistency over time (Lafontaine, 2016). Habitus is a practice production scheme system as well as a system of perception and appreciation schemes for practice (Udasmoro, 2012). Habitus, in the form of Vaillancourt's perception toward suicide and its relation to psychological problems is resulting practical consequences in the form of actions that bring psychologist to school.

Referring to Bourdieu's theory, habitus is a disposition system that operates in a realm (champ). The realm is basically a place of competition and struggle. It is a place of struggle between individuals and groups (Bourdieu, 1980; Haryatmoko, 2014). The realm of the school and students who have habitus of the understanding toward suicide is the realm of meaning and perspective. Not long after school activities are restarting, news comes from a student named Shanel. After the suicide at his school, he had nightmares and did not want to go to school. This caused his parents to decide to expel him from the school.

Vaillancourt: Ah, Bachir, Les parents de Shanel sont venus me voir. Et bien ... ils vont retirer la petite. Elle fait des cauchemars, elle ne veut plus revenir ici. Alors, bien ... c'est sa dernière journée. Vous, ça va?

Vaillancourt: Ah, Bachir, Shanel's parents came to see me. They will transfer their child to another school. He's having nightmares, he doesn't want to come back here anymore. So, well ... this is his last day. You have no problem with that? (00.13.29)

Shannel's behavior is considered a form of traumatic experience that he experiences after the suicide incident. Suicidal events can leave trauma, anxiety, and PTSD (post-traumatic stress disorder). PTSD is an anxiety disorder that can occurs after experiencing or witnessing a traumatic event (Ayuningtyas, 2018), such as suicide. Shanel's parents consider the suicide is causing an adverse effect on their child's psychological condition, so that their actions are a form of "geographic" solution, where the person left by the person who committed suicide moves to a new area to try and erase the memory of death by starting a new life (Olson, 2013), in an effort to restore psychological conditions. 


\section{Suicide as Social Taboo}

The adult group also tends to connect suicide with social taboo issues. It is described in the film, a student named Alice presents a text that shocks Lazhar by bringing up Martine's suicide which he has been trying to avoid at school. Lazhar goes to Vaillancourt to ask permission to distribute the text at school. However, Vaillancourt refused.

Lazhar : Je suis venu vous demander la permission de polycopier le texte et le distribuer à l'école.

Lazhar: I would like to ask your permission to reproduce this text sheet and distribute it at school.

Vaillancourt : Pourquoi?

Vaillancourt : Why?

Lazhar: Il y a dans ce texte, une volonté de communiquer, un désir de parler de la mort ensemble.

Lazhar: In this text, there is a desire to convey, also a desire to speak of death.

Vaillancourt: Non.

Vaillancourt : No. (00.42.59)

Vaillancourt's refusal to Lazhar's request occurred when he heard the word "death". Discussing of death and the end of life have always been taboo in many countries in the world (Sussman, 2019). In Canada, "death" related to suicide is a topic that Vaillancourt tries to avoid. As a senior group, Vaillancourt defines death, particularly suicide as a topic that should not be discussed. Meanwhile Lazhar, who is sympathetic to the students, explains that the text is the students' implicit desire to express grief which certainly involves talking about Martine and his death. However, in the end, he has no other choice but to follow Vaillancourt's perspective as the headmaster.

In addition, problem also occurrs when a student named Simon is called by the headmaster after he was caught carrying a picture of Martine. In the picture, there are pen drawings in the form of wings and a rope that tied the neck of the teacher who committed suicide. The teachers are surprised because it shows the scene of self hanging. A teacher named Audrée scolds him for bringing the picture.

Audrée: Bon, la petite Emmanuelle a vu la photo. Ça l'a complètement chavirée. (...) Qu'est-ce t'avais d'affaire à te promener avec ça, toi? Tu veux l'encadrer, c'est ça que tu veux? Il est pas normal!

Audrée: Emmanuelle has seen that picture. It really took him by surprise. (...) Why are you carrying that picture? Do you want to frame it, is that what you want? He's not normal! (00.58.56)

Audrée was angry when she found it that because she thought that it could trigger fear and a bad memory for the students. Audrée reacted after she saw the reaction of her student, Emmanuelle, who accidentally saw the picture. This shows the unusual form of presumption concerning people who commit suicide. 
In addition, in a meeting held with the headmaster, Lazhar mentioned the "grief" of the students, especially after seeing the problem with the picture brough by Simon.

Lazhar : Ce qui concerne les parents, c'est le deuil des enfants. Punissons l'escarmouche, mais la photo de Simon indique un problème plus significatif.

Lazhar: What worries parents is the grief of their children. We might punished students for their petty bickering, but Simon's picture indicates a more significant problem.

Audrée : Vous insinuez quoi, là?

Audrée: What do you want to mention here?

Lazhar : Je n'insinue rien. Je parle du deuil des enfants, de l'école.

Lazhar: I didn't mention anything. I'm talking about the grief of children, the sorrow that school goes through. (01.01.47)

Lazhar alludes to Simon's picture and shows a problem that implies the necessity to discuss about Martine as it relates to the emotional state of the students. Thinking that Lazhar wanted to bring up Martine's suicide that should have been avoided at school, Audrée rebuked Lazhar. Her action was a form of refusal to discuss about Martine.

In addition, at the meeting, Audrée accidentally brought up the case that had happened between Simon and Martine at school. There has been a misunderstanding due to allegations of harassment by Martine toward Simon. The teachers understood Martine's actions, who at that time only tried to hug Simon for crying and did not prolong the problem. According to the teachers, Martine was a gentle and kind person to others.

Later, one of the teachers named Gaston mentioned the education system in schools, which prohibits physical contact between teachers and students. The prohibition is aimed at avoiding misunderstanding.

Gaston: Parce que ... parce que le moniteur avait pas le droit de lui mettre de la crème solaire. Aujourd'hui, il faut aimer travailler avec les enfants comme on travaille avec des résidus radioactifs. Pas touche, sinon tu te brûles.

Gaston: Because ... because the supervisory instructor can't help him to apply sunscreen. In this day, we should love working with children as much as we do with radioactive residues. Don't touch them, otherwise you will hurt yourself. Gaston: Martine, elle a consolé le petit avec une accolade Elle s'est brulée. Elle a trouvé ça tough.

Gaston: Martine, she's trying to comfort that kid with a hug. She injured herself. It depressed her. (01.03.03)

This incident shows a picture of how the education system that is very strict in a particular case can cause difficulties and feelings of pressure on teachers. Their profession which demands a lot of interaction with students make physical contact both intentional and unintentional difficult to avoid. If it goes on for a long time, the 
chances of them experiencing mental stress during work are very high. If Martine is still alive, her experience with Simon makes her depressed, in the long run it can lead to negative thoughts and perceptions both about her and the environment where she works. Therefore, there is a possibility that this experience can be one of the factors that trigger suicide. Martine may find it difficult to integrate with existing regulations. Based on Durkhéim's theory (Durkheim, 1897 in Little, 2014), from a sociological point of view, suicide is divided into several types based on the strength of a person's social integration with the community. Regarding the case that Martine has experienced, the act of suicide can be categorized as fatalistic suicide which means that this suicide occurs in a situation where the values and norms prevailing in society increase and feel excessive (Upe, 2010: 103 in Biroli, 2018). Fatalistic suicide is suicide that occurs because the rules are very strong and severely restrict the movement of society. Oppressive values and norms make people only obey and obey a policy (Biroli, 2018). Martine's suicide could have been triggered by a cause related to the rules or norms that were too strict in her life, particularly in her work environment. In addition to psychiatric illness, suicidal actions can be triggered by stress in the work environment (Milner et al., 2018). Additionally, her incident with Simon could be considered a negative experience that allowed her to have suicidal thoughts. Negative events in life can be a factor associated with individual thoughts / ideas for suicide (Dupéré et al., 2009; Grover et al., 2009), and suicidal actions (Kumar et al., 2006; Laglaoui Bakhiyi et al., 2017; Liu \& Tein, 2005; Yen et al., 2005). The perspective that suicide is caused by psychological problems is still deeply rooted in the world community (Oexle et al., 2017), supported by many studies that reveal the relationship among the risk of suicide in people suffering from mental illness (Brådvik, 2018).

\section{Suicide and Stigma}

Suicide as a stigma occurs in most people in the world with different cultural backgrounds (Keller et al., 2019) and different religions (Eskin, 2020). This is also shown in the film. In the film, a school staff member shows Lazhar Martine's belongings that are kept in a box in the school warehouse because Pierre, Martine's husband, does not come to collect them up.

Staff : Ce qu'il y avait dans son pupitre. On a appelé son mari. Il est pas venu. J'allais jeter tout ça. J'ai pense qu'il y avait peut-être quelque chose d'utile.

Staff: These are the items that are on her desk. We have contacted her husband, but he did not come. I was going to throw this away. But I thought there might still be something useful. (01.05.13)

Suicide events often cause trauma to the people around them, particularly those who are left behind. In Harvard Health Publishing website, people who have been left behind by suicide have mixed feelings such as anger, feeling rejected, or abandoned. Suicide can be seen as neglect or rejection of those around who care about it (Kirnandita \& Putsanra, 2018). Pierre could feel that Martine left him by committing suicide. Therefore, he ignored it by not taking her belongings at school. People who commit suicide are often seen as acting selfish, cowardly, and often 
their actions are considered treasonous. This assumption is one of the factors that strengthen the stigma that exists in society today (Olson, 2013).

Approaching the end of the film, Lazhar brings up the topic of suicide when two of his students, Alice and Simon, are at the top of their conflict. Lazhar discuss about Martine's suicide with the students to stop the conflict between his students. However, this made him summoned by Vaillancourt.

Vaillancourt : Fallait que t'en rajoutes sur le suicide de Martine?

Vaillancourt: Should you talk about Martine's suicide with them?

Lazhar: En rajouter? Ce sont eux qui ont décidé d'aborder le sujet.

Lazhar: Talk about it? They were the ones who decided they wanted to bring up the incident.

Vaillancourt : Bachir, niaise-moi pas. Depuis le début tu veux déterrer Martine. En plus, t'as ajouté le texte d'Alice dans ta lettre aux parents de Simon. Alors que je t'avais demandé de laisser tomber...

Vaillancourt: Bachir, don't try to fool me. From the start you wanted to bring up Martine. Besides, you added Alice's text in the letter you gave to Simon's parents. In fact, I have asked you to ... (01.23.39)

Vaillancourt is angry after finding out that Lazhar brought up the topic of Martine's suicide in class. In addition, Lazhar sends Alice texts that bring up Martine's suicide to Simon's parents. In the end, his actions lead to his dismissal, and other reason that his status as a refugee from Algeria already known. This incident shows that the domination of the party with a higher position and power is often unavoidable. Vaillancourt occupies a dominating position. In a realm, there are always parties who dominate the game. Domination strategies vary widely depending on the type of realm. Domination is determined by capital ownership, habitus, and capital placement strategy (Udasmoro, 2014). Vaillancourt has a symbolic capital in the form of a higher stand and position than the students and the teachers in the realm of school or education.

Apart from symbolic capital, schools also have cultural capital in their habitus. Cultural capital can be in the form of certificates, knowledge, cultural codes, ways of speaking, writing skills, ways of characterizing, ways of socializing that play a role in determining social position (Bourdieu, 1980: 214-5, 1994: 20-46; Haryatmoko, 2014). In the context of this problem, the school brings a habitus in the form of understanding or values that are adhered to in the event or act of suicide. The capital they have dominates in the realm of schools due to they are the party that implementing policies.

Habitus of the school which tends to be stigmatic towards suicide later has an effect on their professional performance in school. After inviting a psychologist, they took the step of not talking about Martine at all at school. Therefore, Lazhar's efforts to bring Martine's conversation up in class violate the boundaries they have set regarding how to deal with the situation after a suicide incident.

Referring to Bourdieu's theory, social agents in a realm have different ownership of capital and habitus. In the film, the differences in the capital and 
habitus of the school and the students cause them to have different perspective and contradictory attitudes towards suicide. Habitus appears in the form of responses and practical actions of agents in interacting with reality (Safitri, 2015), which in this context takes the form of a suicide. Each agent has a different capital and habitus, but is mutually contradicting each other (Krisdinanto, 2016). Contestation or what Bourdieu also called as a struggle, fight, or battle in the arena or realm does not have a physical meaning, but is symbolic (Krisdinanto, 2016). The school and students supported by Lazhar contest their point of view when facing a suicide incident.

Table 1. Summary of Discussion on the Meaning of Suicide by the School (Senior Group)

\begin{tabular}{|c|c|c|}
\hline \multicolumn{3}{|c|}{ The Meaning of Suicide by the School (Senior Group) } \\
\hline $\begin{array}{c}\text { Suicide and } \\
\text { Psychological Problems }\end{array}$ & Suicide as Social Taboo & Suicide and Stigma \\
\hline $\begin{array}{l}\text { The school action in } \\
\text { bringing in a } \\
\text { psychologist is practical } \\
\text { consequence of its } \\
\text { habitus in the form of } \\
\text { perception of the } \\
\text { connection between } \\
\text { suicide and } \\
\text { psychological problems }\end{array}$ & 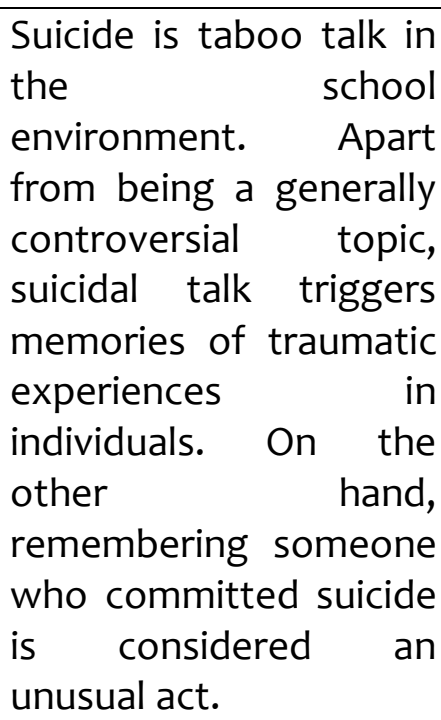 & $\begin{array}{l}\text { The mixed feelings (sadness, } \\
\text { anger, disappointment) that } \\
\text { the person left with } \\
\text { committed suicide make } \\
\text { them ignore the death of } \\
\text { the person who committed } \\
\text { suicide. Stigma is caused by } \\
\text { the assumption that suicide } \\
\text { is an act of selfishness, } \\
\text { cowardice, and a form of } \\
\text { betrayal of those around } \\
\text { who care about the person. }\end{array}$ \\
\hline
\end{tabular}

\section{The Meaning of Suicide by the Students (Young Group)}

Students who are in fact a young age group have a different perspective of suicide. They tend to see suicide as a personal issue, and an individual experience that needs to be expressed. The following are their thought patterns described in the film.

\section{Suicide as a Topic for Discussion}

When Lazhar enters the classroom for the first time, he is faced with an awkward atmosphere due to he is faced with a student who is staring at the place where Martine committed suicide.

Lazhar: Qu'est ce que tu regardes?

Lazhar: What are you looking at?

Un élève:...

A Student :...

Abdel Malek : C'est là que Martine s'est pendue. 
Abdel Malek: That's where Martine committed suicide. (00.12.32)

The class was quiet when Martine's name was mentioned. The school's awkward calm demeanor and avoidance of Martine's talk put students in the same situation. They could not express their grief after Martine's suicide. Activities at school resumed without anything happening, including the final tribute ceremony for Martine. On the other hand, the students were still confused and question the reason for the teacher's suicide. Many people often question the reasons for suicide, which is in contrast to the fact that they do not talk about suicidal thoughts (Fulginiti \& Frey, 2019). In the film, the students do not know that the teacher has suicidal thoughts before it actually happens.

Marie : Mes parents capotent.

Marie: My parents messed up.

Alice : Pas toi?

Alice : You don't?

Marie :(Silence)

Marie : (Silence)

Un élève : Maudite marde! Pourquoi elle a fait ça, Martine?

A Student : Damn it! Why did Martine do that? (00.08.20)

It can be seen from the conversation above, a student named Marie tells of her panic after the suicide incident. This shows different reactions from the two parties when facing the suicide incident, two parties, namely the students and their parents. Parents show panicked, confused, and worried reactions to their children. While the students showed reactions that tended to be calm, even though Martine's departure made them confused. Grief cannot be expressed due to Martine died by suicide, a way that was subject to strong stigmatization of society. Reactions like this are natural for people who have been left behind by those who have committed suicide. The people left behind can only be stunned by the suicide of their relatives or people they know. They are in a state of vague mourning and may be asking themselves if they can do something to prevent death. Death due to suicide is very different from mourning that occurs after natural death (Cvinar, 2005). The mourning process, which is already a very troublesome moment, is added to the burden of suicidal stigmatization in society.

The moment when Alice presented the text she had written in class was the beginning of bringing up the suicide incident with its discussion always avoided.

Alice : ... Mais dans cette belle école-là, que Martine Lachance, elle s'est pendue... avec son foulard bleu après le gros tuyau un mercredi soir. Ma mère, elle était à Miami à cause qu'elle pilote de l'air. J'aurais aimé ça qu'elle revienne tout de suite ... parce que j'ai vraiment trouvé ça très dur. Martine Lachance était sûrement découragée de la vie. La dernière chose qu'elle a faite, c'est de kicker sur sa chaise pour qu'elle tombe. Dès fois là, je me demande, si elle a voulu passer un message violent. Nous, quand on est violents, on nous punit en 
retenue. Mais on peut pas mettre Martine Lachance en retenue parce qu'elle est morte.

Alice:... But in this beautiful school, Martine Lachance hanged herself... in a blue scarf that hangs over a large pipe on Wednesday night. At the time, my mother was in Miami because she was a pilot. I want her to come home soon ... because I'm having a really hard time. Martine Lachance really gave up on life. The last thing she did was kick the chair down so she could fall. Several times, I have wondered if she wanted to send a violent message. We, when we do violence, we are punished. But we can't punish Martine Lachance because she's dead. (00.40.01)

The class fell silent after Alice read the text. Broadly speaking, the text begins with an expression of sorrow for Martine's death. She experienced a difficult period of mourning because the suicide deaths were difficult for people to accept. The period of mourning for the death of someone who has committed suicide is considered different from natural death. Suicide death has a very deep emotional impact on the family, friends, and colleagues of the victim, even beyond the impact of sudden death (Carpiniello \& Pinna, 2017). However, even so, this does not make suicide something forbidden to talk about. Alice had a period of mourning, but that did not make her want to avoid talking about the Martine incident.

\section{Suicide and Particular Causes other than Psychological Problems}

After reading the text, Alice comes into conflict with Simon. Through the text, she intended to blame Simon for Martine's death due to an incident that had occurred.

Alice : Toi, tu as quelque chose à dire?

Alice : You, do you have anything to say?

Simon: Qu'est-ce que je t'ai fait?

Simon : What did I do to you?

Alice : C'est pas ce que tu m'as fait. C'est ce que t'as fait à Martine.

Alice : It's not about what you've done to me. It's about what have you done to Martine?

Simon : Quoi?

Simon: What?

Alice : Ce que t'as dit à tout le monde.

Alice : About what you have done to everbody.

Simon: Tu sais rien, toi. Tu m'énerves!

Simon : You have no idea! You make me mad! (00.44.39)

The implied meaning in Alice's text indicates that although she considers Martine's suicide to be a form of violence (to herself) and deserves punishment, she considers that there are other people who are also responsible and deserving of punishment. This matter shows Alice's assumption concerning the existence of a certain cause behind Martine's suicide. Therefore, she appointed Simon as a person to blame and held accountable. This is a form of interpretation in the form of 
perception that the event of death must be accompanied by a certain reason or logical effect. This is in contrast to the meaning of the senior group on suicide who considered it as an action that is always related to psychological problems. Suicide is often seen as an action triggered by psychological disorders, although various factors related to the life background of the perpetrator can also be reviewed.

Alice's action is a form of grief that was not well expressed after Martine's suicide so that she was channeled by blaming others. Not to mention, the school which is the party that should mediate the grief, tries not to talk about the facts concerning what happened to Martine. This shows the fact that suicide deaths are covered by stigmatization.

\section{Suicide and Traumatic Experiences}

Martine's suicide talks reoccur when Lazhar is teaching a class and a student named Victor tells his grandfather's suicide that he heard from his mother. Later, as the topic of suicide continued to be discussed, Lazhar asked the other students if they had also discussed suicide with their parents. A student named Marie expressed his opinion concerning the suicide incident.

Lazhar : D'autres ont parlé du suicide avec leurs parents?

... Si quelqu'un veut parler librement, il peut le faire.

Lazhar: Did the others talk about suicide with the parents?

... If anyone has an opinion, please say so.

Marie : Tout le monde pense qu'on est traumatisés à vie. Mais moi, je pense que c'est les adultes qui sont traumatisés.

Marie : Everyone think that we're traumatized by life. But I think it's the adults who are traumatized. (01.16.41)

According to Marie, the adults reaction, namely the school's excessive avoidance of Martine's talk, showed that they were more traumatized than the students. In fact, the students had difficulty expressing their grief due to they were focused on the adult panic and their excessive direction.

Table 2. Summary of Discussion on the Meaning of Suicide by the Students (Young Age Group)

\begin{tabular}{|c|c|c|}
\hline \multicolumn{3}{|c|}{ The Meaning of Suicide by the Students (Young Age Group) } \\
\hline $\begin{array}{c}\text { Suicide as a Topic for } \\
\text { Discussion }\end{array}$ & $\begin{array}{c}\text { Suicide and Particular } \\
\text { Causes other than } \\
\text { Psychological Problems }\end{array}$ & $\begin{array}{c}\text { Suicide and Traum } \\
\text { Experiences }\end{array}$ \\
\hline $\begin{array}{l}\text { Students cannot } \\
\text { express their grief due } \\
\text { to the school avoids } \\
\text { talking about suicide. } \\
\text { However, the } \\
\text { conversation concerning } \\
\text { suicide was brought up } \\
\text { when a student read out }\end{array}$ & $\begin{array}{l}\text { Students have } \\
\text { perceptions concerning } \\
\text { the relationship of the } \\
\text { suicide act with } \\
\text { particular causes / } \\
\text { background experiences } \\
\text { of the perpetrator. In } \\
\text { the film, the incident }\end{array}$ & $\begin{array}{l}\text { Post-suicide traumatic } \\
\text { experiences are more } \\
\text { visible to schools who are } \\
\text { adults than students. The } \\
\text { problems experienced by } \\
\text { the students were more } \\
\text { specifically the difficulty } \\
\text { expressing grief due to the }\end{array}$ \\
\hline
\end{tabular}




\begin{tabular}{llll}
\hline her text in class which that occurred between school avoided talking \\
contained a statement & Simon and Martine is about suicide. & \\
of sympathy and grief & considered by Alice as a \\
for the teacher's death. & $\begin{array}{l}\text { trigger } \\
\text { suicide. }\end{array}$ & & \\
\hline
\end{tabular}

\section{CONCLUSION}

Discussion on the issue of suicide is important and deserves attention. The problem of different perspectives that occur between contradictory parties in society and those who are sympathized with the issue can be understood if the discussion is not continuously avoided. Contradictory perspectives on suicide are caused by differences in the way certain parties interpret the event. In the film Monsieur Lazhar (2011), stigmatic and contradictory perspectives can be analyzed by looking at the attitude of the school after the suicide incident. Meanwhile, an indication of the meaning of suicide that was not judgmental could be seen from the attitude of the students who were accompanied by Lazhar as their substitute teacher. Based on the analysis, the students are still in the search for meaning. An action that triggers conflict between them, like those of the characters Alice and Simon, is an attempt to express grief. This matter due to suicide is a difficult topic to discuss in a school environment.

Based on the analysis that has been done, the school is a senior group who tends to interpret suicide with a special psychological aspect on traumatic and social issues specifically on taboo issues. Suicide is considered a traumatic topic and should be avoided. Meanwhile, students who are in the young age group are more likely to interpret based on their personal problems and personal experiences. Without using social and psychological aspects such as the school, students try to interpret suicide by looking at their past with their teacher. Lazhar's role contributed to the meaning of the students' suicide. His sympathy for the students, led him to make efforts to break the taboo of suicide to be discussed at school. He focused on his students implied desire to express grief. This can be done if the discussion concerning Martine is allowed.

In addition, indications of differences in opinion on suicide can be found by looking at several factors, including the attachment of the school to community stigma, differences in habitus between schools and students, and different age ranges between the two parties which affect the perception of suicide.

\section{REFERENCES}

Adelino A. G. Pereira \& Francisco M. S. Cardoso. (2019). Stigmatising Attitudes Towards Suicide by Gender and Age. CES Psicología, 12(1), 3-16. https://doi.org/10.21615/cesp.12.1.1

Al-Harrasi, A., Al Maqbali, M., \& Al-Sinawi, H. (2016). Surviving a Suicide Attempt. Oman Medical Journal, 31(5), 378-380. https://doi.org/10.5001/omj.2016.74

Ayuningtyas, I. P. I. (2018, October 10). Penerapan strategi penanggulangan penanganan PTSD (Post Traumatic Stress Disorder) pada anak-anak dan remaja. 1st ASEAN School Counselor Conference on Innovation and Creativity in Counseling. https://www.gci.or.id/proceedings/view_article/162/3/ascc-2017 
Biroli, A. (2018). Bunuh Diri Dalam Perspektif Sosiologi. Simulacra, 1(2), 213-223. https://doi.org/10.21107/sml.v1i2.4996

Bourdieu, P. (1980). Questions de sociologie (The Question of Sociology). Minuit.

Bourdieu, P. (1994). The Field of Cultural Production: Essays on Art and Literature (R. Johnson, Trans.). Columbia University Press.

Brådvik, L. (2018). Suicide Risk and Mental Disorders. International Journal of Environmental Research and Public Health, 15(9), 2028. https://doi.org/10.3390/ijerph15092028

Carpiniello, B., \& Pinna, F. (2017). The Reciprocal Relationship between Suicidality and Stigma. Frontiers in Psychiatry, 8. https://doi.org/10.3389/fpsyt.2017.00035

Cvinar, J. G. (2005). Do suicide survivors suffer social stigma: A review of the literature. Perspectives in Psychiatric Care, 41(1), 14-21. https://doi.org/10.1111/j.0031-5990.2005.00004.x

Dumesnil, H., \& Verger, P. (2009). Public Awareness Campaigns About Depression and Suicide: A Review. Psychiatric Services, 60(9), 1203-1213. https://doi.org/10.1176/ps.2009.60.9.1203

Dupéré, V., Leventhal, T., \& Lacourse, E. (2009). Neighborhood poverty and suicidal thoughts and attempts in late adolescence. Psychological Medicine, 39(8), 1295-1306. https://doi.org/10.1017/S003329170800456X

Eskin, M. (2020). Suicidal Behavior in the Mediterranean Countries. Clinical Practice and Epidemiology in Mental Health, 16(1). https://doi.org/10.2174/1745017902016010093

Evans-Lacko, S., Henderson, C., \& Thornicroft, G. (2013). Public knowledge, attitudes and behaviour regarding people with mental illness in England 2009-2012. The British Journal of Psychiatry, 202(s55), \$51-s57. https://doi.org/10.1192/bjp.bp.112.112979

Foo, X. Y., Mohd. Alwi, Muhd. N., Ismail, S. I. F., Ibrahim, N., \& Jamil Osman, Z. (2014). Religious Commitment, Attitudes Toward Suicide, and Suicidal Behaviors Among College Students of Different Ethnic and Religious Groups in Malaysia. Journal of Religion and Health, 53(3), 731-746. https://doi.org/10.1007/s10943-012-9667-9

Fulginiti, A., \& Frey, L. M. (2019). Exploring suicide-related disclosure motivation and the impact on mechanisms linked to suicide. Death Studies, 43(9), 562-569. https://doi.org/10.1080/07481187.2018.1504349

Grover, K. E., Green, K. L., Pettit, J. W., Monteith, L. L., Garza, M. J., \& Venta, A. (2009). Problem solving moderates the effects of life event stress and chronic stress on suicidal behaviors in adolescence. Journal of Clinical Psychology, 65(12), 1281-1290. https://doi.org/10.1002/jclp.20632

Harada, K., Eto, N., Honda, Y., Kawano, N., Ogushi, Y., Matsuo, M., \& Nishimura, R. (2014). A comparison of the characteristics of suicide attempters with and without psychiatric consultation before their suicidal behaviours: A crosssectional study. BMC Psychiatry, 14(1), 146. https://doi.org/10.1186/1471-244X14-146 
Haryatmoko. (2014, December 10). Habitus dan Kapital dalam Strategi Kekuasaan (Teori Strukturasi Pierre Bourdieu dengan Orientasi Budaya). Lecture Series, Ruang Sidang 1 FIB UGM. https://fib.ugm.ac.id/2014/12/habitus-dan-kapitaldalam-strategi-kekuasaan.html

Karnanta, K. Y. (2013). Paradigma Teori Arena Produksi Kultural Sastra: Kajian Terhadap Pemikiran Pierre Bourdieu. Poetika : Jurnal Ilmu Sastra, 1(1), Article 1. https://doi.org/10.22146/poetika.v111.10420

Keller, S., McNeill, V., Honea, J., \& Paulson Miller, L. (2019). A Look at Culture and Stigma of Suicide: Textual Analysis of Community Theatre Performances. International Journal of Environmental Research and Public Health, 16(3), 352. https://doi.org/10.3390/ijerph16030352

Kirnandita, P., \& Putsanra, D. V. (2018). Beban Berlapis Orang-Orang yang Ditinggal Bunuh Diri. tirto.id. https://tirto.id/beban-berlapis-orang-orang-yang-ditinggalbunuh-diri-cC1K

Krisdinanto, N. (2016). Pierre Bourdieu, Sang Juru Damai. Kanal: Jurnal Ilmu Komunikasi, 2(2), 189-206-206. https://doi.org/10.21070/kanal.v2i2.300

Kumar, C. T. S., Mohan, R., Ranjith, G., \& Chandrasekaran, R. (2006). Characteristics of high intent suicide attempters admitted to a general hospital. Journal of Affective Disorders, 91(1), 77-81. https://doi.org/10.1016/j.jad.2005.12.028

Lafontaine, S. (2016). Quid de l'habitus?. Réflexions en compagnie de Pierre Bourdieu et d'Edmund Husserl. Revue de l'Institut de Sociologie, 86, 119-134. http://journals.openedition.org/ris/401

Laglaoui Bakhiyi, C., Jaussent, I., Beziat, S., Cohen, R., Genty, C., Kahn, J.-P., Leboyer, M., Le Vaou, P., Guillaume, S., \& Courtet, P. (2017). Positive and negative life events and reasons for living modulate suicidal ideation in a sample of patients with history of suicide attempts. Journal of Psychiatric Research, 88, 64-71. https://doi.org/10.1016/j.jpsychires.2016.12.022

Leo, N. (2018, May 16). 3 Azab Mengerikan dalam Islam Ini Akan Diterima oleh Setiap Pelaku Bunuh Diri-Pos Kupang. Pos-Kupang. https://kupang.tribunnews.com/amp/2018/05/16/islam-melarang-orangbunuh-diri-beginilah-azab-pelaku-bunuh-diri-dalam-islam

Linggasari, Y. (2015, November 9). WHO: Tiap 40 Detik, Satu Orang Mati Bunuh Diri. CNN Indonesia. https://www.cnnindonesia.com/nasional/20150911134959-2078094/who-tiap-40-detik-satu-orang-mati-bunuh-diri

Little, W. (2014). Introduction to Sociology-1st Canadian Edition. OpenStax College. https://opentextbc.ca/introductiontosociology/

Liu, X., \& Tein, J.-Y. (2005). Life events, psychopathology, and suicidal behavior in Chinese adolescents. Journal of Affective Disorders, 86(2-3), 195-203. https://doi.org/10.1016/j.jad.2005.01.016

Mannarini, S., \& Boffo, M. (2015). Anxiety, bulimia, drug and alcohol addiction, depression, and schizophrenia: What do you think about their aetiology, dangerousness, social distance, and treatment? A latent class analysis approach. Social Psychiatry and Psychiatric Epidemiology, 50(1), 27-37. https://doi.org/10.1007/s00127-014-0925-X 
Milner, A., Witt, K., LaMontagne, A. D., \& Niedhammer, I. (2018). Psychosocial job stressors and suicidality: A meta-analysis and systematic review. Occupational and Environmental Medicine, 75(4), 245-253. https://doi.org/10.1136/oemed-2017-104531

Na, K.-S., Oh, K.-S., Lim, S.-W., Ryu, S.-H., Lee, J.-Y., Hong, J. P., \& Cho, S.-J. (2018). Association between age and attitudes toward suicide. The European Journal of Psychiatry, 32(1), 44-51. https://doi.org/10.1016/j.ejpsy.2017.08.007

Nursalam, N., \& Nugrawati, N. (2018). Gantung Diri Sebagai Penyimpangan Sosial Terhadap Norma Agama. Equilibrium: Jurnal Pendidikan, 6(1), 44-52. https://doi.org/10.26618/equilibrium.v6i1.1799

Oexle, N., Ajdacic-Gross, V., Kilian, R., Müller, M., Rodgers, S., Xu, Z., Rössler, W., \& Rüsch, N. (2017). Mental illness stigma, secrecy and suicidal ideation. Epidemiology and Psychiatric Sciences, 26(1), 53-60. https://doi.org/10.1017/S2045796015001018

Olson, R. (2013). Suicide and Stigma. Centre for Suicide Prevention. https://www.suicideinfo.ca/resource/suicideandstigma/

O'Reilly, D., \& Rosato, M. (2015). Religion and the risk of suicide: Longitudinal study of over 1 million people. The British Journal of Psychiatry, 206(6), 466-470. https://doi.org/10.1192/bjp.bp.113.128694

Quidu, M. (1983). La prévention du suicide. Soins. Psychiatrie, 32-33, 31-34. http://olib.balamand.edu.lb/webview?infile=details.glu\&loid=96527\&rs $=3223$ 85\&hitno $=1$

Safitri, A. N. (2015). Pergulatan Iman Budhi Santosa untuk Mencapai Posisi Terkonsekrasi dalam Arena Sastra Yogyakarta. Poetika: Jurnal Ilmu Sastra, 3(2), Article 2. https://doi.org/10.22146/poetika.v3i2.10441

Siauw, B. P. (2018, July 26). Bahaya Bagi Kesehatan Jiwa dalam Berita Bunuh DiriRemotivi. Remotivi. https://www.remotivi.or.id/amatan/478/bahaya-bagikesehatan-jiwa-dalam-berita-bunuh-diri

Stack, S., \& Kposowa, A. J. (2011). Religion and Suicide Acceptability: A CrossNational Analysis. Journal for the Scientific Study of Religion, 50(2), 289-306. https://doi.org/10.1111/j.1468-5906.2011.01568.x

Sussman, T. (2019, October 25). To die well, we must talk about death before the end of life. The Conversation. http://theconversation.com/to-die-well-we-musttalk-about-death-before-the-end-of-life-124256

Tichote. (2010, August 19). Parler du suicide, c'est tabou: Ne pas en parler c'est un crime. AgoraVox. http://www.agoravox.fr/actualites/sante/article/parler-dusuicide-c-est-tabou-ne-79732

Udasmoro, W. (2012). Pendidikan Karakter dalam Sastra Anak. Sastra Prancis Universitas Gadjah Mada.

Udasmoro, W. (2014). Konstruksi Indentitas Remaja dalam Karya Sastra. Program Studi Sastra Prancis Universitas Gadjah Mada.

Windfuhr, K., \& Kapur, N. (2011). Suicide and mental illness: A clinical review of 15 years findings from the UK National Confidential Inquiry into Suicide. British Medical Bulletin, 100(1), 101-121. https://doi.org/10.1093/bmb/ldro42 
Yen, S., Pagano, M. E., Shea, M. T., Grilo, C. M., Gunderson, J. G., Skodol, A. E., McGlashan, T. H., Sanislow, C. A., Bender, D. S., \& Zanarini, M. C. (2005). Recent life events preceding suicide attempts in a personality disorder sample: Findings from the collaborative longitudinal personality disorders study. Journal of Consulting and Clinical Psychology, 73(1), 99-105. https://doi.org/10.1037/0022-006X.73.1.99 